\title{
The Challenge of the South China Sea: Congressional Engagement and the U.S. Policy Response
}

James M. Scott

Texas Christian University

\begin{abstract}
Maritime territorial disputes in Asia are increasingly contentious, with competing claims and confrontations among numerous states of the region carrying significant implications for the relations among the countries of the region, between the U.S. and the region, and for the broader US-China relationship. This analysis examines the politics of the U.S. approach to the challenge, focusing on the role of Congress as a factor shaping the U.S. response. After establishing an analytical framework that directs attention to legislative-executive interactions and the domestic political/institutional context, it assesses the consequences of this context for U.S. policies and approaches to the problem. The analysis reveals the sequence and dynamics of congressional engagement, by which members moved from indirect and non-legislative approaches to direct and legislative approaches to narrow the boundaries and the shape the direction of US foreign policy. It concludes by addressing the implications for the U.S. approach and the relationships among the key parties.
\end{abstract}

Keywords: Congress, foreign policy, diplomacy, South China Sea, maritime territorial disputes

\section{Introduction}

The stakes are high in the South China Sea as territorial disputes and China's increasingly assertive claims pose challenges for its neighbors in the region and for the United States. While China accuses the U.S. of meddling in what its leaders routinely characterize as China's historic claims to the disputed area, U.S. policymakers seek to chart a course that firmly addresses China's claims and accompanying threats and assertive actions, protects U.S. interests in the region, supports its friends and allies in the region, but avoids escalating the tension unnecessarily.

However, these efforts to respond to the South China Sea challenge are shaped by actors other than the executive branch. Making sense of U.S. diplomacy and its policy approach to this potentially volatile territorial issue requires attention not only to the presidency, but also to members of Congress. As Garrison describes it, "the struggle for the China agenda is usually one between members of Congress who represent competing interests (and corresponding lobbying groups) and the administration, which focuses on the general health of the bilateral relationship." From the original post-World War II China Lobby to the pro-Taiwan lobby

\footnotetext{
James M. Scott, Herman Brown Chair and Professor, Department of Political Science, Texas Christian University. Email: j.scott@tcu.edu.

1 Jean Garrison, Making China Policy: From Nixon to G.W. Bush (Boulder, CO: Lynne Rienner, 2005), 3.
} 
to the current context of human rights, religious freedom, national security, and business interests, competing agendas and priorities in Congress have often played an important role in shaping U.S. policy toward China. Hence, incorporating the role of the U.S. Congress is essential to understanding U.S. foreign policy making.

This analysis presents an interpretive case $s t u d y^{2}$ of the pattern of engagement of the U.S. Congress in shaping U.S. diplomacy and policy response to the challenge of the South China Sea in the 2014-2015 period. This social science case study approach applies an established, "conceptual framework that focuses attention on some theoretically specified aspects of reality" to a case - a set of events bounded by space and time -to provide better understanding of the events and explanations of their nature. ${ }^{3}$ This approach thus provides explanation of the processes and outcomes of a specific case, but also sheds light on the case as a member of a broader class of phenomena, ${ }^{4}$ and offers insights on the utility and, in some instances, limits, of the theoretical/analytical framework.

I argue that approaching this case through the lens of congressional engagement in foreign policy sheds light on both the processes and outcomes of foreign policymaking. Focusing on the central question about congressional engagement, I first establish an analytical/conceptual framework for understanding/explaining U.S. foreign policymaking that calls attention to the nature of the policymaking process and the avenues and activities of congressional influence. I then apply that framework to interpret U.S. foreign policymaking in one period of the South China Sea dispute, highlighting key phases and activities in the policymaking process from 2014-2015. Focusing on this set of events within these time boundaries has several purposes and advantages. First, China's actions and the tensions in the region accelerated significantly in late 2013, presenting a "new" problem on the foreign policy agenda. Second, the 2014-2015 period presents two legislative/budgetary cycles to observe administration action and congressional engagement. Third, the consequences of congressional elections in November 2014, in which the House remained in the hands of the Republican majority, but the Senate flipped from Democrat to Republican control, offers a glimpse into the effects of changing political context. The analysis concludes with a brief summary of subsequent events and policymaking activities after January 2016, and consideration of the implications of the dynamics revealed in the analysis.

\section{The Analytical Lens: Congress and the Politics of U.S. Foreign Policy}

Understanding the U.S. response to the South China Sea dispute demands more than assessing the problem, considering U.S. interests, and looking to the White House for its decisions and actions. U.S. foreign policy takes shape through a complicated institutional structure, and it can be both complex and messy. Members of Congress are often significant players but gauging their roles and impact requires attention of several key features of the institutional context and the nature of the legislative-executive relationship.

A framework to examine congressional behavior and decisions on whether and how to engage on foreign policy issues such as the South China Sea dispute — and contribute to a

See A. Lijphart, "Comparative politics and the comparative method," American Political Science Review 65, no. 3 (1971): 682-93. This approach is also labelled case-explaining or theory-guided. See J. Levy, "Case Studies: Types, Designs, and Logics of Inference," Conflict Management and Peace Science 25 (2008): 1-18; S. Van Evera, Guide to Methods for Students of Political Science (Ithaca, New York: Cornell University Press, 1997).

3 Levy, "Case Studies," 4-5.

4 A. George and A. Bennett, Case Studies and Theory Development in the Social Sciences (Cambridge, MA: MIT Press, 2005), 
better understanding of how and why the U.S. response to the South China Sea in particular has unfolded as it has - rests on three components. First, two clarifications must be made to provide the foundation to understanding the congressional role and influence in U.S. foreign policy in general: a) incorporating the range of actors comprising Congress, from the collective institution to its individual members; b) recognizing multiple avenues of congressional influence. Second, the cues and conditions that motivate congressional foreign policy behavior and help explain the patterns of legislative-executive interaction must be incorporated. Finally, based on these two foundations, one can understand general patterns of legislative-executive interactions and congressional engagement and influence on the U.S. response to the South China Sea dispute.

\subsection{Setting the context}

Understanding congressional activity and influence on the South China Sea dispute first requires clarifying what is meant by "Congress" as a foreign policy actor. Most generically, "Congress" may represent the institution as a whole, or one or the other of its two chambers, with a corresponding focus on formal legislative outputs. Within each chamber, there are numerous committees and subcommittees where policy is shaped. Policy can also be shaped in caucuses focusing on specific policy issues or regions. Party organizations and leadership also play an increasingly important role both as an access point and in developing foreign policy positions. ${ }^{5}$

However, "Congress is not truly an 'it' but a 'they," " and its 535 individual members each have their own political and policy agendas. ${ }^{6}$ It is individual members who highlight issues, help set the governmental agenda, frame debate, introduce bills, and lobby their colleagues and administration officials for their support. ${ }^{7}$ As others have noted, "Congress does not check presidential power, individuals within it do." ${ }^{18}$ Some of these individual MCs are especially interested in foreign policy and often take the initiative. In general, those interested in forcing policy innovation in Congress have been called "congressional foreign policy entrepreneurs," issue leaders, and other similar labels. ${ }^{9}$ Such entrepreneurs are not only generally more interested and attentive to foreign policy, but they are also generally more assertive, and more committed to initiating policy change or innovation. ${ }^{10}$, According to one scholar, such members regularly attempt to "seize the initiative to identify policy problems and offer substantive alternatives and solutions." ${ }^{11}$ While such individual members

\footnotetext{
5 See Burdett Loomis and Wendy Schiller, The Contemporary Congress, 5th ed. (Belmont, CA: Wadsworth Publishing, 2005); Susan Webb Hammond, "Congressional Caucuses in the Policy Process," in Congress Reconsidered, 4th ed., ed. Lawrence Dodd and Bruce Oppenheimer (Washington: CQ Press, 1989); Steven Smith, "Congressional Party Leaders," in The President, The Congress, and the Making of Foreign Policy, ed. Paul E. Peterson (Norman, OK: University of Oklahoma Press, 1994).

6 Andrew Rudalevige, "The Executive Branch and the Legislative Process," in The Executive Branch, ed. Joel D. Aberbach and Mark A. Peterson (New York: Oxford University Press, 2005), 428.

7 Ralph Carter and James M. Scott, Choosing to Lead: Understanding Congressional Foreign Policy Entrepreneurs (Durham, NC: Duke University Press, 2009).

8 William Howell and Jon Pevehouse, While Dangers Gather: Congressional Checks on Presidential War Powers (Princeton, NJ: Princeton University Press, 2007), 34.

9 Carter and Scott, Choosing to Lead; Rebecca Hersman, Friends and Foes: How Congress and the President Really Make Foreign Policy (Washington, DC: Brookings, 2000); See also John Kingdon, "Models of Legislative Voting," Journal of Politics 39 (1977): 563-95; Yongjoo Jeon and Donald Haider-Markel, "Tracing Issue Definition and Policy Change: An Analysis of Disability Issue Images and Policy Response,” Policy Studies Journal 29 (2001): 215-31.

${ }_{10}$ Carter and Scott, Choosing to Lead.

11 Richard Conley, "Congress, the Presidency, Information Technology, and the Internet: Policy Entrepreneurship at Both Ends of Pennsylvania Avenue," in Congress and the Internet, ed. James A. Thurber and Colton C. Campbell (Upper Saddle River, NJ: Prentice-Hall, 2003), 136.
} 
may seek to pass legislation, they frequently engage in many less formal actions and they usually take the lead in congressional efforts to shape foreign policy.

The second important contextual factor for assessing and understanding legislativeexecutive interaction between Congress and the president is an accurate accounting of the avenues of influence available to members of Congress. The Constitution assigns the president powerful but numerically limited foreign policy roles in Article 2, Section 2, including commander-in-chief. The application of these powers, combined with court decisions and the growth of executive institutions under the command of the president have established important opportunities and precedents for presidential leadership. However, in Article I, Section 8, the Constitution assigns Congress more numerous and more specific foreign policy powers to add to the general legislative power (Section 1) and the power to appropriate funds (Section 7): to collect duties; provide for the common defense; regulate foreign commerce; set uniform rules for naturalization of citizens; punish piracy and "other Offences against the Law of Nations"; declare war; raise and support armies and navies; regulate land and naval forces; organize, arm, discipline, and call forth the militia; and make all necessary laws to carry out such powers.

However, "members of Congress exert influence over foreign policy through many formal and informal inquiries, investigation, floor statements, and various procedural customs and techniques"12 As indicated in Table 1, four broad avenues of influence emerge from differentiating between legislative vs. nonlegislative actions and direct vs indirect actions: ${ }^{13}$ direct-legislative, indirect-legislative, direct-nonlegislative, and indirect-nonlegislative. ${ }^{14}$ Most scholars focus on the kinds of activities that fall in the direct-legislative category (such as substantive legislation aimed at particular policy outputs), but procedural efforts (including procedural legislation aimed at shaping the decision process), oversight, signaling, framing, and other indirect legislative and nonlegislative approaches are influential as well. ${ }^{15}$

\begin{tabular}{c|c|c}
\hline Table 1- Avenues of Congressional Foreign Policy Influence \\
\hline & Direct & Indirect \\
\hline \multirow{3}{*}{ Legislative } & Legislation & Nonbinding Legislation \\
& Appropriations & Procedural Legislation \\
& Appointments (Senate) \\
\hline \multirow{2}{*}{ Nonlegislative (Senate) } & Letters/Phone Calls & Agenda Setting \\
& Consultations/Advising & Framing Debate \\
& Hearings & Foreign Contacts \\
\hline
\end{tabular}

Source: Adapted from James M. Scott, "In the Loop: Congressional Influence in American Foreign Policy," Journal of Political and Military Sociology 25 (Summer 1997): 47-76.

As important, distinguishing between these avenues calls attention to a very important characteristic of congressional activity and influence: the role of anticipated reactions. As Lindsay noted, "Just as chess players consider their opponent's possible moves and plan

\footnotetext{
12 Hersman, Friends and Foes, 20.

13 James M. Scott, "In the Loop: Congressional Influence in American Foreign Policy," Journal of Political and Military Sociology 25 (1997):47-76; James M. Scott and Ralph Carter, "The Not-So-Silent Partner: Patterns of Legislative-Executive Interaction on the War on Terror," International Studies Perspectives 15, no. 2 (2014): 186-208.

${ }^{14}$ Legislative actions pertain to the passage of specific pieces of legislation. Nonlegislative actions do not involve a specific item of legislation. Direct actions are specific to both the issue involved and the case at hand. Indirect actions include those that seek to influence the broader political context or setting.

15 James Lindsay, Congress and the Politics of US Foreign Policy (Baltimore, MD: Johns Hopkins University Press, 1994).
} 
several steps ahead, Congress and the executive branch anticipate one another's behavior and modify their own behavior accordingly." ${ }^{\prime 16}$ In this context, members can use any of the avenues to prompt presidents to accommodate their preferences (or risk facing legislative resistance later). Essentially, this aspect of congressional influence refers to the use of signals (e.g., hearings, speeches, letter) the threat of congressional legislative action (e.g., non-binding resolutions, introducing legislation), and the use of that threat as leverage by members to bring administration proposals or actions into line with their preferences. Thus, while anticipated reactions are not an avenue of influence per se (and are thus not represented in Table 1), they constitute a signaling/leverage strategy through which such avenues can be employed. Such congressional signaling or conditioning can play an important role in foreign policy decisions, even if legislation itself never results. ${ }^{17}$

\subsection{Cues and conditions ${ }^{18}$}

With these clarifications as the foundation, understanding the role, actions and influence of Congress in the South China Sea dispute further requires addressing the cues and conditions that motivate congressional foreign policy behavior. Members of Congress are motivated by a wide variety of cues (factors members consider) and conditions (situational characteristics) of the policy context/structure. Among the most significant of these cues and conditions are public opinion, policy preferences, partisanship, the nature of the policy process, differences in policy type and issue, and policy instruments. ${ }^{19}$ Particular configurations of these factors help to explain the patterns of legislative-executive interaction: Congress may be compliant, competitive or confrontational, and no single form or sequence prevails.

Public Opinion. Congress is "the people's branch" and its members are powerfully driven by political calculations related to public opinion and reelection concerns. ${ }^{20}$ With respect to foreign policy, these concerns have several dimensions. First, members are attentive to broad public opinion regarding the president, with popular presidents and popular policies more likely to receive support than unpopular ones. Moreover, policies regarded by the public as failures are likely targets for congressional activity and assertiveness. Second, members are attuned to constituency opinion and tend not to stray far from the broad preferences of their districts or states (or the preferences of those who fund their campaigns).

Partisanship. Foreign policy is an increasingly partisan process, and partisan calculations provide significant cues for member activity and assertiveness. While partisanship is not necessarily the driving force behind all congressional activism and assertiveness in U.S. foreign policy, its impact has expanded since the Vietnam War. Presidential party members have a partisan reason to support the president or to work with or through the administration where possible. Conversely, opposition party members are quicker to challenge presidents and to promote their own alternative foreign policy initiatives. ${ }^{21}$ As one study concluded, the

16 James Lindsay, "Congress and Foreign Policy: Why the Hill Matters,” Political Science Quarterly 107 (1993): 613. On anticipated reactions, see also Carl J. Friedrich, Constitutional Government and Democracy: Theory and Practice in Europe and America, rev.ed. (Boston: Little, Brown, 1941), 589-91.

17 Lindsay, Congress and the Politics of US Foreign Policy; Howell and Pevehouse, While Dangers Gather; Carter and Scott, Choosing to Lead. See also Douglas Kriner, After the Rubicon: Congress, Presidents, and the Politics of Waging War (Chicago, IL: The University of Chicago Press, 2010).

18 This section builds on and draws on Scott and Carter, "The Not-So-Silent Partner," 191-93.

19 Carter and Scott, Choosing to Lead; Scott and Carter, "The Not-so-Silent Partner".

20 David Mayhew, America's Congress: Actions in the Public Sphere, James Madison through Newt Gingrich (New Haven, CT: Yale University Press, 2000); Kingdon, "Models of Legislative Voting".

21 Carter and Scott, Choosing to Lead; Howell and Pevehouse, While Dangers Gather. 
impact of partisanship on foreign policy has increased in nearly every way imaginable over the past several decades. ${ }^{22}$

Policy Preferences. While members weigh public opinion, constituency views, and partisan calculations, they are also strongly motivated by their own preferences and ideology, which are in in turn, shaped by their personal experiences and values. ${ }^{23}$ Member policy preferences, as typically measured by ideological predisposition and their personal interest in creating good public policy, are central to congressional behavior in foreign policy. ${ }^{24}$

Policy Process and Timing. The foreign policy process is cyclical, typically proceeding with initial formulation-decision-implementation phases linked to subsequent iterations of these phases. While the initial cycle of policy making is usually dominated by the executive branch, subsequent cycles afford members of Congress opportunities to play a significant role. Annual budget authorization/appropriation cycles and oversight responsibilities establish regular opportunities for policy evaluation and "hard-wire" members into the process, so members frequently rely on such cycles to engage on issues of concern and try to shape policies. Thus, it is not uncommon for congressional foreign policy activity to occur at predictable times in the legislative calendar, with early spring, mid-summer, and early fall as particularly common access points.

Policy Context. As others have argued, different foreign policy contexts tend to involve distinct legislative-executive orientations. ${ }^{25}$ By their nature, crises — or even high-stakes or high-threat issues - favor the executive and push Congress to the background, at least for a time. In a crisis, the need for a speedy response often leads presidents to keep the decision unit as small as possible; members of Congress are rarely invited to participate. ${ }^{26}$ Although some may complain about being left out, most members either rally in support of the president's response to the crisis, arguing that the country needs to present a united front to the provocateur or defer for a time. ${ }^{27}$ Yet true crises are infrequent, and extended crisis decision making tends to invite congressional second-guessing. ${ }^{28}$ The sense of 'crisis' inevitably recedes and invites later involvement by members.

Non-crisis foreign policy can be divided in two types: structural and strategic. The conventional wisdom long held that the presidency dominates strategic decisions - those

22 C. James DeLaet and James M. Scott, "Treaty Making and Partisan Politics: Arms Control and the U.S. Senate, 1960-2001," Foreign Policy Analysis 2 (2006): 177-200. On partisanship in foreign policy, see, for example, Steven Hurst, "Parties, Polarization, and US Foreign Policy," in Obama and the World: New Directions in US Foreign Policy, $2^{\text {nd }}$ edition, ed. Inderjeet Parmar, Linda B. Miller, and Mark Ledwidge (New York, NY: Routledge, 2014); Ashley Jochim and Bryan D. Jones, "Issue Politics in A Polarized Congress," Political Research Quarterly 66, no. 2 (2013): 352-69; James McCormick and Eugene Wittkopf, "Bipartisanship, Partisanship, and Ideology in Congressional-Executive Foreign Policy Relations, 1947-1988," Journal of Politics 52 (1990): 1077100; James McCormick, Eugene Wittkopf, and David Danna, "Politics and Bipartisanship at The Water's Edge: A Note on Bush and Clinton," Polity 30, no. 1 (1997):133-50. Peter Trubowitz and Nicole Mellow, "Foreign Policy, Bipartisanship and the Paradox of Post-September 11 America," International Politics 48 (2011):164-87.

${ }_{23}$ Carter and Scott, Choosing to Lead; DeLaet and Scott, "Treaty-Making and Partisan Politics"; Barry Burden, Personal Roots of Representation (Princeton, NJ: Princeton University Press, 2007).

24 James McCormick and Neil J. Mitchell, "Commitments, Transnational Interests, and Congress: Who Joins the Congressional Human Rights Caucus?" Political Research Quarterly 60 (2007):579-92

25 Randall Ripley and Grace Franklin, Congress, the Bureaucracy, and Public Policy (Pacific Grove, CA: Brooks/Cole, 1990); Randall Ripley and James Lindsay, "Foreign and Defense Policy in Congress: An Overview and Preview," in Congress Resurgent: Foreign and Defense Policy on Capitol Hill, ed. Randall Ripley and James Lindsay (Ann Arbor, MI: University of Michigan Press, 1993).

26 Charles Hermann, International Crises: Insights from Behavioral Research (New York: Free Press, 1972); Charles Hermann, ed., When Things Go Wrong: Foreign Policy Decision Making under Adverse Feedback (New York: Routledge, 2011).

27 J. William Fulbright, The Crippled Giant: American Foreign Policy and Its Domestic Consequences (New York: Random House, 1972); John Oneal and Anna Lillian Bryan, "The Rally 'Round the Flag Effect in U.S. Foreign Policy Crises: 1950-1985," Political Behavior 17 (1995):379-401.

28 Peter Schraeder, United States Foreign Policy toward Africa: Incrementalism, Crisis and Change (Cambridge: Cambridge 
involving the basic ends of foreign policy - while Congress was more comfortable in making structural foreign policy - as it dealt with the means to implement those ends. However, numerous studies suggest members are increasingly likely to address strategic issues since the early Cold War years. ${ }^{29}$ Indeed, many members seek out strategic foreign policy issues whenever they see a policy vacuum or a need for a policy correction (see below).

Policy structure. As just noted, differences between policy corrections and policy vacuums are also significant. In policy corrections, members need to overcome the inertia of existing policy, persuading the president to change course. Policy failures are especially inviting targets for correction, especially when public opinion is activated, and members are particularly active in efforts to shape policymaking in these situations. In contrast, vacuums - when problems are identified but policy actions have not been taken - present members with opportunities to act in contexts less dominated by other stakeholders, especially in the executive branch. Members identifying such vacuums relevant to problems that matter to them engage in activities to convince the administration to address the problem in ways that conform to member preferences, and/or to convince enough other members to act through legislative avenues to persuade or force the president to respond. ${ }^{30}$

Policy Instrument. It is also helpful to distinguish between executive-dominated instruments and legislative-dominated instruments. ${ }^{31}$ Policies relying on the use of force, diplomacy, and intelligence activities are usually initiated by the executive branch, with Congress generally playing a more reactive role. Other policies, such as those relying on aid and tied more closely to the annual authorization/appropriation cycle, are more amenable to congressional initiative.

\subsection{Constructing the analytical framework}

The combination of the conceptual clarifications and the cues/conditions discussed above leads to some general expectations for the role/influence of Congress and patterns of legislative-executive interactions that provide a useful lens through which to examine and interpret the congressional role and activity on the South China Sea dispute. Together, they contribute to a better understanding of the nature of the U.S. response and the impact of members of Congress on it. Moreover, they call attention to the rhythms and patterns of congressional engagement on the issue.

Drawing on the clarifications and insights just introduced to interpret the role of Congress in U.S. foreign policymaking on the South China Sea dispute during the 2014-2015 period, a simple starting point is to differentiate between initial phases of the policymaking process and subsequent iterations of the policy process. ${ }^{32}$ Within this simple structure, a number of patterns and sequences can be introduced to develop the analytical lens for application to the South China Seas dispute.

Initial Cycle. The insights from the preceding section suggest that initial foreign policymaking phases begin with problem recognition and response. In this initial process cycle, the administration is most likely to take the initiative, especially in cases of higher

29 Carter and Scott, Choosing to Lead; Howell and Pevehouse, While Dangers Gather; Lindsay, Congress and the Politics of U.S. Foreign Policy.

30 See Gregory Wawro, Legislative Entrepreneurship in the U.S. House of Representatives (Ann Arbor: University of Michigan Press, 2001); Douglas Arnold, The Logic of Congressional Action (New Haven: Yale University Press, 1990).

${ }_{31}$ Robert Pastor, Whirlpool: US Foreign Policy toward Latin America and the Caribbean (Princeton, NJ: Princeton University Press, 1992).

32 Scott and Carter, "The Not-so-Silent Partner". 
stakes/threat environment. ${ }^{33}$ Members of Congress typically respond to initial phases with substantial deference to presidential leadership. Compliance with presidential initiatives is common at the outset, especially in crisis or potential crisis situations. Individual members often engage in basic framing activities that reflect problem recognition and signal their concerns, as well as "surveillance" of administration actions to monitor policy responses. However, beyond such indirect and non-legislative activities, most members take a "wait and see" approach, leaving more extensive attention to the handful of individual members with particular interests in the problem (entrepreneurs).

Subsequent Cycles. As the initial administration response unfolds, members of Congress react, and congressional engagement increases in later process cycles. ${ }^{34}$ The nature of that adjustment/engagement is contingent on several factors. In some circumstances, member engagement is essentially supportive. This is particularly likely with policy success, with relatively high public approval of the policy and/or president, and with co-partisans. In such success situations, members may engage in "band-wagoning" or bidding wars to out-do a president in responding to a situation, effectively proposing increased efforts in line with the general administration policy response. ${ }^{35}$ However, with unsuccessful policy, lack of policy response, and/or low public approval, congressional engagement is generally more competitive, especially among partisan opponents of the president. Furthermore, to the extent that a high-stakes crisis or potential crisis extends in time, members are more likely to engage competitively as well. ${ }^{36}$ Here, members are more likely to make "balancing" or "prodding" efforts to resist or redirect administration initiatives.

In any case, these variants can be expected to emerge in general accordance with a common dynamic reflecting several key characteristics. First, individual members with relatively high levels of attention, interest and engagement (entrepreneurs) typically take the lead. ${ }^{37}$ Second, individual and congressional activity and assertiveness is likely to begin in non-legislative and indirect avenues (oversight, framing, signaling) and then extend to more direct and legislative approaches (procedural and/or substantive legislation) ${ }^{38}$ Third, on any given foreign policy issue, congressional activity and assertiveness is likely to begin in legislative-dominated instruments (e.g., budgets) and then extend to executive-dominated instruments (e.g., strategy statements; use of military). Fourth, on a given issue, changes in the partisan balance in Congress are likely to lead to greater/lesser assertiveness (depending on the direction of the shift vis-à-vis the party of the president).

Extended Cycles. The role and activity of Congress in extended cycles is highly contingent on a variety of factors, but may escalate to legislative-executive confrontation. The first contingency is the problem development itself. In some situations, policy developments result in a defusing of the issue, which can lead to a reduction of engagement by Congress (e.g., a crisis is averted or resolved). A second contingency depends on presidential responsiveness. Administrations that respond to congressional activity by adjusting policy essentially purchase some combination of compliance and surveillance/monitoring until

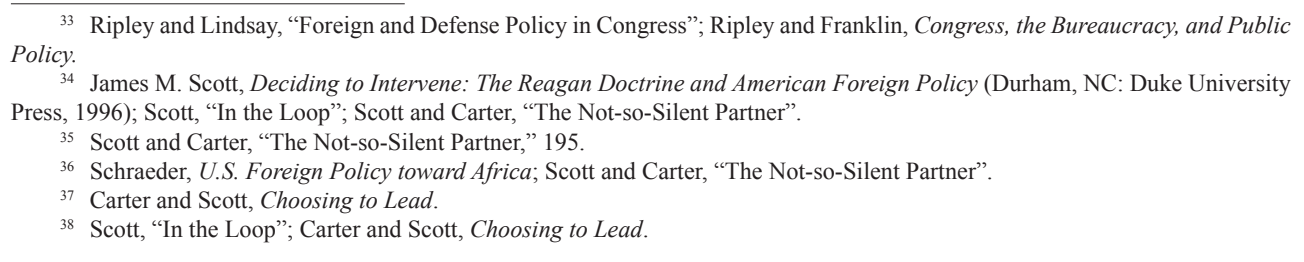


subsequent policy developments take shape and trigger further engagement (or resolution). Non-responsiveness - rejection of congressional preferences/proposals (defiance) or failure to act (policy vacuums) invites greater assertiveness, engagement, and more independent policymaking efforts by members. ${ }^{39}$ In either case, both public opinion and partisanship continue to play a role, with unpopular presidents/policies inviting more confrontational efforts, and partisan divisions generating more policy challenges.

With these expectations in mind, this explanatory framework sheds light on U.S. policymaking on the South China Sea dispute in 2014-2015. Applying this lens calls attention to the role and impact of members of Congress in shaping the U.S. response, the patterns and sequences of their engagement, and the limits and conditional constraints on their influence.

\section{Applying the Lens: Congress and the South China Sea, 2014-2015}

Long-standing concerns over the numerous territorial disputes in the South China Sea escalated after 2013 - in particular those involving the Paracel Islands, Spratly Islands, and the Scarborough Shoal. China claims approximately 90\% of the South China Sea, relying on what has been characterized as the "nine-dash line" to demarcate its territorial assertions. Tension increased beginning late 2013 as China ramped up its actions through a series of incremental steps — often described as a "salami-slicing strategy" — to push the status quo in favor of its assertions and change the strategic context without taking any individual step so dramatic as to trigger a significant military confrontation. These incremental actions included small steps to gradually take control of smaller reefs and islands within the South China Sea, establishing settlements on many, operating and expanding naval patrols in the area, gradually leasing oil and fishing blocks inside areas claimed by neighboring countries, sending naval patrols to harass and impede other countries' development efforts in the area, dredging and developing smaller reefs and islands for military and economic use, and other steps.

Additionally, China and the U.S. are locked in a dispute over China's claims to rights to control the activities of foreign military forces (i.e., the U.S. Navy) in what it asserts is its Exclusive Economic Zone. Clashes over access and activity in this disputed zone led to a series of incidents between China and the U.S. from 2001 on. At the heart of these concerns are the U.S. assertion and defense of "Freedom of Navigation" rights in the regions (and generally). In 2014, China's actions escalated to include a program of activity to build and expand a series of reefs and islands in the South China Seas to further establish and extend its claims, leading to heightened tension in the region. ${ }^{40}$ Fears that China is engaged in a strategy to extend its control over the "near-seas" area, which includes the South China Sea, led the U.S. and other states in the regions to take action in defense of their strategic, political, and economic interests.

39 James M. Scott and Ralph Carter, "Acting on the Hill: Congressional Assertiveness in U.S. Foreign Policy," Congress \& the Presidency 29 (2002):151-69; Carter and Scott, Choosing to Lead.

40 To be sure, reclamation efforts in the South China seas are not new and China is not the only claimant to engage in this activity. As a recent Defense Department report stated, "All territorial claimants, except Brunei, maintain outposts in the South China Sea, which they use to establish presence in surrounding waters, assert their claims to sovereignty, and monitor the activities of rival claimants. All of these claimants have engaged in construction-related activities....Though other claimants have reclaimed land on disputed features in the South China Sea, China's latest efforts are substantively different from previous efforts both in scope and effect. The infrastructure China appears to be building would enable it to establish a more robust power projection presence into the South China Sea." See Department of Defense, “Asia-Pacific Maritime Security Strategy," undated, released August 2015, http:// www.defense.gov/Portals/1/Documents/pubs/NDAA\%20A-P_Maritime_SecuritY_Strategy-08142015-1300-FINALFORMAT. PDF, 16-7. 


\subsection{Phase 1: "Managing differences" and the administration response}

As the tension over the South China Sea escalated, during the period of this analysis (20142015), members of Congress engaged in framing and oversight/surveillance, expressing concerns over the issue and monitoring the administration response. These activities were concentrated in the most interested members on the foreign policy and armed services committees. Concerns with actions by the Obama Administration (Democratic Party) were more critically expressed in the House of Representatives (controlled by Republicans) than in the Senate (controlled by Democrats).

As the problem developed, the administration responded with actions and declarations building on the broad foundations of existing U.S. policy, including the administration's "Asia pivot" initiative and bilateral relations with China. As Daniel Russel, assistant secretary of state for East Asia, explained it to the Senate Foreign Relations Committee in the spring of 2014, cooperation on economic issues, expansion of military-to-military coordination and regional security initiatives, and collaboration on regional and global issues like nonproliferation (Korea, Iran) and climate change were critical elements of the broader bilateral relationship. In the context of these larger issues, Russel characterized the South China Sea matters as part of "managing differences" in the overall (and generally positive) relationship. As Russel put it in testimony before the U.S. Senate:

\footnotetext{
In the Asia-Pacific region, Beijing's neighbors are understandably alarmed by China's increasingly coercive efforts to assert and enforce its claims in the South China and East China Seas. A pattern of unilateral Chinese actions in sensitive and disputed areas is raising tensions and damaging China's international standing. Moreover, some of China's actions are directed at U.S. treaty allies. The United States has important interests at stake in these seas: freedom of navigation and overflight, unimpeded lawful commerce, respect for international law, and the peaceful management of disputes. We apply the same principles to the behavior of all claimants involved, not only to China. ${ }^{41}$
}

Emphasizing the broader U.S. - China relationship, a number of principles formed the foundation of the specific issue of the South China Sea. These included emphasis on:

- U.S. neutrality on the competing claims to sovereignty in the area;

- the U.S. commitment to peaceful settlement of disputes and consistency with the principles of international law by all parties;

- support for the principle of freedom of the seas;

- the precepts of customary international law respecting territorial waters and exclusive economic zones, especially the principles that states may regulate economic activities is such zones, but not foreign military activities (freedom of navigation) or surveillance flights above international waters;

- restraint by claimants and respect for the status quo until peaceful settlement is reached, especially regarding land reclamation efforts. ${ }^{42}$

As Secretary of State John Kerry put it later in 2014 (in the context of a speech on the administration's efforts to rebalance or pivot to Asia):

${ }^{41}$ U.S. Senate, Committee on Foreign Relations, The Future of U.S.-China Relations, Hearing, June 25, 2014 (S. Hrg. 113-460) (Washington: Government Printing Office, 2014), https://www.gpo.gov/fdsys/pkg/CHRG-113shrg91140/html/CHRG113shrg91140.htm.

${ }^{42}$ Ronald O'Rourke, Maritime Territorial and Exclusive Economic Zone (EEZ) Disputes Involving China: Issues for Congress (CRS Report No. R42784) (Washington, DC: Congressional Research Service, December 22, 2015). 
The United States is not a claimant, and we do not take a position on the various territorial claims of others. But we take a strong position on how those claims are pursued and how those disputes are going to be resolved. So we are deeply concerned about mounting tension in the South China Sea and we consistently urge all the parties to pursue claims in accordance with international law, to exercise self-restraint, to peacefully resolve disputes, and to make rapid, meaningful progress to complete a code of conduct that will help reduce the potential for conflict in the years to come. And the United States will work, without getting involved in the merits of the claim, on helping that process to be effectuated, because doing so brings greater stability, brings more opportunity for cooperation in other areas. ${ }^{43}$

In addition, the administration took steps to promote coordination and cooperation in the region. These steps included moves to bolster cooperative relationships with U.S. friends and allies in the region. For instance, the administration worked to expand naval and maritime engagement with Indonesia, Malaysia, and Vietnam, among others. The administration also undertook a number of efforts to address potential clashes between U.S., Chinese, and other claimants' commercial and military transit and activities. For example, in 2014, China participated for the first time in the Rim of the Pacific naval exercises, or RIMPAC. According to the U.S. Department of Defense this step provided "an opportunity for the United States, China, and countries throughout the Asia-Pacific region to exercise key operational practices and procedures that are essential to ensuring that tactical misunderstandings do not escalate into crises. ${ }^{~} 4$ Additionally, in 2014 Secretary of Defense Chuck Hagel led efforts to establish codes of conduct to avoid clashes. In the spring, 21 Pacific rim countries, including the U.S. and China, agreed to a non-binding protocol called the "Code for Unplanned Encounters at Sea" (CUES), which outlined "safety procedures, basic communications, and basic maneuvering instructions for naval ships and aircraft during unplanned encounters at sea, with the aim of reducing the risk of incidents arising from such encounters." Later in 2014, Hagel and his Chinese counterpart signed a Memorandum of Understanding (MOU) on rules of behavior for safety of air and maritime encounters, including rules of behavior for safety during surface-to-surface encounters. ${ }^{45}$

Assistant Secretary of State Russel summarized the administration approach to the issue under questioning from Sen. Bob Corker, the Republican ranking member of the Senate Foreign Relations Committee in a hearing in June 2014:

\begin{abstract}
we use public messaging, we use diplomacy. We also engage in building the capacity of the countries in Southeast Asia to ensure that they are able to adequately police their own territorial waters and that they can maintain the domain awareness that ensures that they know what is going on in their contiguous waters or in the open seas. Our strategy, Senator, includes the support for a unified and influential ASEAN [Association of SouthEast Asian Nations], and we believe that the call from the ASEAN countries to China to work with them, not to bully them, has a long-term salutary effect. Lastly, the fact of the matter is that the robust military presence, the strong security commitments, and the healthy alliances that the United States maintains with many countries in the region similarly serves to maintain stability and keep the peace, going forward, as it has for the last six decades. ${ }^{46}$
\end{abstract}

43 John Kerry, "Remarks on U.S.-China Relations" (Remarks at the Johns Hopkins School of Advanced International Studies Washington, DC, November 4, 2014), http://www.state.gov/secretary/remarks/2014/11/233705.htm.

44 See Department of Defense, "Asia-Pacific Maritime Security Strategy," 25.

${ }^{45}$ Memorandum of Understanding Between The Department of Defense of the United States of America and the Ministry of National Defense of the People's Republic of China Regarding the Rules of Behavior for Safety of Air and Maritime Encounters, November 12, 2014. See Department of Defense, "Asia-Pacific Maritime Security Strategy," 30.

${ }^{46}$ U.S. Senate, The Future of U.S.-China Relations. 
During most of 2014, the congressional reaction to the mounting tension - and the administration response - was cautious and involved indirect and/or non-legislative efforts at framing and "surveillance." For example, as concerns over the South China Sea tension ramped up in late 2013, a number of U.S. senators signaled concern through a letter to China's Ambassador to the United States. Foreign Relations Committee member Robert Menendez (D-NJ, and committee chair), Bob Corker (R-TN), Marco Rubio (R-FL), and Benjamin L. Cardin (D-MD) expressed concern over China's unilateral actions which they argued

\begin{abstract}
"reinforces the perception that China prefers coercion over rule of law mechanisms to address territorial, sovereignty or jurisdictional issues in the Asia-Pacific. It also follows a disturbing trend of increasingly hostile Chinese maritime activities, including repeated incursions by Chinese vessels into the waters and airspace of Japan, the Philippines, Vietnam and other in the East and South China Seas. These actions threaten freedom of air and maritime navigation, which are vital national interests of the United States." ${ }^{\prime 47}$
\end{abstract}

Members of Congress also used hearings to raise their concerns about the issue and engage in initial oversight over administration responses, which key members found too restrained. For example, on January 14, 2014, the House Armed Services Seapower and Projection Forces subcommittee and the House Foreign Affairs Asia and the Pacific subcommittee held a joint hearing on the maritime disputes. Led by their Republican majority members, the joint session featured testimony by regional specialists from the U.S. Naval War College, the Center for Strategic and International Studies, and the American Foreign Policy Council, and commentary and questions from the subcommittee members designed to call attention to the need to address the problem. As Steve Chabot (R-OH) stated, "There is no other issue right now in the Asia-Pacific region more worrisome than the rise in tensions we are seeing as a result of China's efforts to coercively change and destabilize the regional status quo." ${ }^{48}$ Rep. Randy Forbes (R-VA) further signaled concerns and framed the potential significance of the issue, noting "My greatest fear is that China's coercive methods of dealing with territorial disputes could manifest into increased tensions that could ultimately lead to miscalculation... .I believe we must be 100 percent intolerant of China's territorial claims and its continued resort to forms of military coercion to alter the status quo in the region." 49 Ranking Democratic Party members of the subcommittees also voiced concern, with Ami Bera (DCA) noting "We have got to send, as a body, in a bipartisan manner, a strong message to China that these threatening and provocative moves to assert their maritime territorial claims are unacceptable. These steps clearly undermine the peace and stability of the Asia-Pacific. If China is left unchallenged, China's claims over the region will solidify, thus altering the status quo." ${ }^{50}$ The session's witnesses —none of whom were administration officials collectively recommended firm responses and a concerted strategy to address the problem.

Later that same spring, in hearings before the Senate Foreign Relations Committee's East Asia and Pacific Affairs subcommittee, the Democratic Party majority led by Ben Cardin (DMD) used the topic of U.S.-Taiwan relations to signal concerns over the maritime disputes, hearing testimony from administration witnesses, along with regional specialists from the

${ }^{47}$ Quoted/excerpted in O'Rourke, Maritime Territorial and Exclusive Economic Zone (EEZ) Disputes, 4.

${ }^{48}$ House of Representatives, The Subcommittee on Seapower and Projection Forces of the Committee on Armed Services Meeting Jointly with Subcommittee on Asia and the Pacific of the Committee on Foreign Affairs. Maritime Sovereignty in the East and South China Seas, Hearing, January 14, 2014, (Serial No. 113-137), 2.

${ }^{49}$ House of Representatives, Maritime Sovereignty in the East and South China Seas, 3-4.

${ }^{50}$ House of Representatives, Maritime Sovereignty in the East and South China Seas, 6. 
National Bureau of Asian Research and the Project 2049 Institute. Along with other things, the session included calls for expanded cooperation and support for U.S. friends and allies in the face of China's assertive actions..$^{51}$ Just two months later, in late June the Senate Foreign Relations Committee held additional hearings on U.S.-China relations that also addressed growing concerns about aggressive Chinese actions. ${ }^{52}$ Led by Democrats Robert Menendez (NJ) and Ben Cardin (MD), the hearings were cast in the broad context of bilateral and regional relations and included testimony from the U.S. State Department's head of the Asia bureau and policy analysts from Princeton University and the Kissinger Institute. Raising concerns about the provocative Chinese actions, members from both parties sought information about administration responses, as well as analysis from the outside specialists on the nature, stakes, and potential recourses.

Mounting congressional worries led Menendez to join with Senators Cardin, Rubio (RFL), McCain (R-AZ), Risch (R-ID), Cornyn (R-TX), Leahy (D-VT), and Feinstein (D-CA) to sponsor a resolution (S.Res 412, first introduced in April) signaling their concerns to the administration. This resolution stressed the importance of "freedom of navigation and other internationally lawful uses of sea and airspace in the Asia-Pacific region, and for the peaceful diplomatic resolution of outstanding territorial and maritime claims and disputes," condemned China's actions, and laid out a 13-point statement of U.S. policy:

(1) reaffirm its unwavering commitment and support for allies and partners in the Asia-Pacific region, including longstanding United States policy regarding Article V of the United StatesPhilippines Mutual Defense Treaty and that Article V of the United States-Japan Mutual Defense Treaty applies to the Japanese-administered Senkaku Islands;

(2) oppose claims that impinge on the rights, freedoms, and lawful use of the sea that belong to all nations;

(3) urge all parties to refrain from engaging in destabilizing activities, including illegal occupation or efforts to unlawfully assert administration over disputed claims;

(4) ensure that disputes are managed without intimidation, coercion, or force;

(5) call on all claimants to clarify or adjust claims in accordance with international law;

(6) support efforts by ASEAN and the People's Republic of China to develop an effective Code of Conduct, including the "early harvest" of agreed- upon elements in the Code of Conduct that can be implemented immediately;

(7) reaffirm that an existing body of international rules and guidelines, including the International Regulations for Preventing Collisions at Sea, done at London October 12, 1972 (COLREGs), is sufficient to ensure the safety of navigation between the United States Armed Forces and the forces of other countries, including the People's Republic of China;

(8) support the development of regional institutions and bodies, including the ASEAN Regional Forum, the ASEAN Defense Minister's Meeting Plus, the East Asia Summit, and the expanded ASEAN Maritime Forum, to build practical cooperation in the region and reinforce the role of international law;

(9) encourage the adoption of mechanisms such as hotlines or emergency procedures for preventing incidents in sensitive areas, managing them if they occur, and preventing disputes from escalating;

\footnotetext{
${ }^{51}$ Evaluating U.S. Policy on Taiwan on the 35th Anniversary of the Taiwan Relations: Hearing Before the Senate Committee on Foreign Relations Subcommittee on East Asian and Pacific Affairs, April 3, 2014 (statement of Daniel R. Russel, Assistant Secretary, Bureau of East Asian and Pacific Affairs), https://2009-2017.state.gov/p/eap/rls/rm/2014/04/224350.htm.

52 U.S. Senate, The Future of U.S.-China Relations.
} 
(10) fully support the rights of claimants to exercise rights they may have to avail themselves of peaceful dispute settlement mechanisms;

(11) encourage claimants not to undertake new unilateral attempts to change the status quo since the signing of the 2002 Declaration of Conduct, including not asserting administrative measures or controls in disputed areas in the South China Sea;

(12) encourage the deepening of partnerships with other countries in the region for maritime domain awareness and capacity building, as well as efforts by the United States Government to explore the development of appropriate multilateral mechanisms for a "common operating picture" in the South China Sea that would serve to help countries avoid destabilizing behavior and deter risky and dangerous activities; and

(13) assure the continuity of operations by the United States in the Asia- Pacific region, including, when appropriate, in cooperation with partners and allies, to reaffirm the principle of freedom of operations in international waters and airspace in accordance with established principles and practices of international law. ${ }^{53}$

The full Senate adopted the bipartisan S.Res 412 on July 10, 2014, by unanimous consent.

\subsection{Phase 2: Heightened concerns and congressional reaction}

In the latter half of 2014, tension continued to mount over the South China Sea disputes, China's unilateral efforts continued unabated, and a number of events led members of Congress to begin efforts to exert pressure on the administration to take additional and more forceful action. Among the most salient developments, a clash between Chinese military forces and a U.S. P-8 surveillance plane in August, China's accelerated reclamation efforts, which transitioned in late 2014 to expanded construction and re-purposing of a number sites (including the development of airfields and other facilities designed to project Chinese control), and aggressive assertion of territorial sovereignty in the region combined to heighten concern that a more assertive U.S. response was needed.

Concerns mounted in the latter half of the 2014, even as diplomatic progress on confidence-building measures and other matters occurred. A tense incident in which a Chinese jet challenged a U.S. Navy P-8 patrol aircraft over the South China Seas - which the Department of Defense characterized as "very, very close, very dangerous" 54 — raised concerns in August, which were only modestly allayed by the memorandum of understanding reached in November. ${ }^{55}$ However, in early 2015 when an analyst at the Center for Strategic and International Studies posted an article that compared satellite photography from earlier years to those of late 2014-early 2015, revealing the pace and extent of Chinese activities, it generated significant alarm. ${ }^{56}$

This critical moment galvanized a number of members of Congress to advocate for more aggressive efforts to prepare for and counter the Chinese challenge. To do so in an arena in which the policy instruments (military, diplomacy) favored presidential initiative and leadership, members engaged in a variety of efforts short of direct-legislative actions. As one analyst described, "While the Obama Administration would likely rather continue its present strategy of trying to engage Beijing and work towards some sort of 'new type of great power relations,' it appears a group of lawmakers are working towards pushing the administration

53 See S.Res 412, accessed November 6, 2016, https:/www.congress.gov/bill/113th-congress/senate-resolution/412.

54 Quoted in O'Rourke, Maritime Territorial and Exclusive Economic Zone (EEZ) Disputes, 12.

55 Department of Defense, “Asia-Pacific Maritime Security Strategy,” 14-5.

56 Mira Rapp-Hooper, "Before and After: The South China Sea Transformed," Asia Maritime Transparency Initiative, Center for Strategic and International Studies, February 18, 2015. 
to consider a different approach. Such an approach would likely engage Beijing on a whole range of Indo-Pacific issues - with a specific focus on the challenges in the South China Sea." ${ }^{57}$

For example, a number of members began to communicate their concerns and call for action by what they regarded as a reluctant administration. In the spring (after Republicans gained control of the Senate in the 2014 midterm elections), Senators John McCain (RAZ) and Jack Reed (D-RI), the chair and ranking member of the Senate Armed Services Committee, and Senators Bob Corker (R-TN) and Bob Menendez (D-NJ), the chair and ranking member of the Senate Foreign Relations Committee, sent a letter to Secretary of State John Kerry and Secretary of Defense Ashton Carter urging greater attention to the dispute and advocating for "the development and implementation of a comprehensive strategy for the maritime commons of the Indo-Pacific region." ${ }^{58}$ In what respected former executive branch official, policy analyst and academic Jack Goldsmith characterized as "a strong signal to the administration and to China," ${ }^{59}$ the letter also stated

\begin{abstract}
China's deliberate effort to employ non-military methods of coercion to alter the status quo, both in the South China Sea and East China Sea, demands a comprehensive response from the United States and our partners. While administration officials have highlighted various speeches and initiatives as evidence of a broader strategy, we believe that a formal policy and clearly articulated strategy to address these forms of Chinese coercion are essential. That is why the National Defense Authorization Act of 2015 includes a requirement for a report on maritime security strategy with an emphasis on the South China Sea and East China Sea. ${ }^{60}$
\end{abstract}

In the House of Representatives, Randy Forbes (R-VA), founder of the Congressional China Caucus and chair of the Armed Services Committee Seapower and Projection Forces subcommittee, took another approach, attempting to educate and persuade his colleagues by distributing news and information on China to them and their staffs in a daily publication called The Caucus Brief. ${ }^{61}$

Members also accelerated the use of hearings to press their policy preferences. In 2014, the Senate Foreign Relations Committee held 3 hearings that included significant attention to the South China Seas issue, while the House Foreign Affairs Committee held 6. In 2015, both panels increased their activities: the Senate committee held 7 hearings, while the House committee held $8 .^{62}$ In the Senate, the Armed Services committee increased its hearings on the matter from 2 in 2014 to 7 in $2015 .{ }^{63}$ Notably, the 2014 midterm elections put the Republicans in the majority in Senate for 2015.

In these hearings, members pushed the administration to take action to meet the challenge. For example, in April, both the House and Senate Armed Services committees held hearings in the context of defense authorizations that addressed the threat to U.S. interests that Chinese reclamation/construction work in the South China Sea entailed. In May, the Senate Foreign

57 Harry Kazianis, "Can Congress Stop China in the South China Sea," The National Interest, March 22, 2015, http:// nationalinterest.org/print/feature/can-congress-stop-china-the-south-china-sea-12459.

58 Quoted in Kazianis, "Can Congress Stop China in the South China Sea".

59 Jack Goldsmith, "Letter from Heads of SFRC and SASC to Kerry and Carter on South China Sea," Lawfare, March 20, 2015, https://www.lawfareblog.com/letter-heads-sfrc-and-sasc-kerry-and-carter-south-china-sea.

${ }^{60}$ Quoted in Kazianis, "Can Congress Stop China in the South China Sea".

61 See The Caucus Brief, accessed July 1, 2016, https://forbes.house.gov/chinacaucus/. (The website is no longer active.)

62 See the hearings schedules for 2014-2015 in the Senate Foreign Relations, https://www.foreign.senate.gov/hearings; and House Foreign Affairs committees, https://foreignaffairs.house.gov/hearings-and-markups/.

63 See the hearings schedules for 2014-2015 in the Senate Armed Services committees, https://www.armed-services.senate. gov/hearings. 
Relations Committee convened a session specifically on the South China Sea (and East China Sea) challenge. Two administration officials - Daniel Russel (assistant secretary of state for Asia) and David Shear (assistant secretary of defense for Asian and Pacific security affairs) were challenged by members of both parties in an effort to push the administration into greater action. Sen. Bob Corker (R-TN) the committee chair flatly stated "I am concerned that absent a course correction, specifically high-level and dedicated engagement from the United States Government to articulate a coherent China policy, our credibility will continue to suffer throughout the region, whether it is in regards to nonproliferation or preserving freedom of navigation in the East and South China Seas." ${ }^{64}$ After lengthy questioning and prodding by members from both parties, Corker concluded by saying:

it just again builds on the narrative that there is a lot of talk coming out of the administration, with not much follow-through. And I do hope that somehow we will develop a coherent policy relative to China that somehow, while they violate international norms in multiple ways, we can figure out a way for a price to be paid.... But I think you should leave here today with a sense of disappointment from both sides of the aisle about us not really having, still, a coherent policy. The reason this hearing is taking place today is, a year ago, we were concerned about the fact that the United States does not have a coherent policy relative to these issues and others with China....I leave here as disappointed as I was a year ago about the fact that we do not have a policy. ${ }^{65}$

A series of other hearings occurred in both houses of Congress, as key members such as Menendez, Corker, Forbes, and others on the foreign affairs and armed services committee in both chambers continued to press the administration for both attention and action. The House Foreign Affairs Subcommittee on Asia held highly critical hearings in July to highlight security interests and threats in the South China Sea (no administration officials testified), ${ }^{66}$ while the armed services committees in both houses and the Senate Foreign Relations followed up with additional hearings in September. ${ }^{67}$ Throughout the series of hearings, members also regularly pressed for more tangible support for allies and friends in the region, including Japan, the Philippines, Vietnam, and others.

Finally, members of Congress used the annual budget cycle to take the lead and introduce a variety of bills to direct funds and attention to the issue. For example, in early 2015 the Senate took the lead and, in a "bidding war" action doubling down on initial administration efforts, added language to the 2015 concurrent resolution on the budget that allowed funds to be allocated:
to supporting a comprehensive multi-year partner capacity building and security cooperation plan in the Indo-Pacific region, including for a regional maritime domain awareness architecture and for bilateral and multilateral exercises, port calls, and training activities of the United States Armed Forces and Coast Guard to further a comprehensive strategy to strengthen United States alliances and partnerships, freedom of navigation, and the unimpeded access to the maritime commons of the Asia-Pacific. ${ }^{68}$

\footnotetext{
${ }^{64}$ The U.S. Senate, Committee on Foreign Relations. Safeguarding American Interests in the East and South China Seas Hearing, May 13, 2015 (S.Hrg. 114-75) (Washington: Government Printing Office, 2015), 3, https://www.gpo.gov/fdsys/pkg/CHRG114shrg96850/html/CHRG-114shrg96850.htm.

${ }_{65}$ The U.S. Senate, Safeguarding American Interests in the East and South China Seas, 40.

${ }^{66}$ House of Representatives, Subcommittee on Asia and the Pacific of the Committee on Foreign Affairs. America's Security Role in the South China Sea, Hearing, July 23, 2015 (Serial No. 114-77) (Washington: Government Printing Office, 2015), http:// docs.house.gov/meetings/FA/FA05/20150723/103787/HHRG-114-FA05-Transcript-20150723.pdf.

${ }^{67}$ E.g., The U.S. Senate, Subcommittee on East Asia, the Pacific and International Cybersecurity Policy of the Senate Foreign Relations Committee. The Changing Landscape of U.S.-China Relations: What's Next? Hearing, September 29, 2015, https://www. foreign.senate.gov/hearings/the-changing-landscape-of-us-china-relations-whats-next.

${ }_{68}$ Quoted in O'Rourke, Maritime Territorial and Exclusive Economic Zone (EEZ) Disputes, 46.
} 
Both the House and Senate included various sections to promote support and funding for a number of initiatives directed toward key states involved in the dispute, including Taiwan, the Philippines, and Vietnam. In early May, key senators took it upon themselves to introduce a proposal in the defense authorization bill in the spring to move beyond the existing approach and support and assist friends and allies more extensively in the region. This new "South China Sea Initiative," authorized over \$400 million for assistance and training to Indonesia, Malaysia, the Philippines, Thailand, Vietnam, Brunei, Singapore, and Taiwan, "for the purpose of increasing maritime security and maritime domain awareness of foreign countries along the South China Sea." ${ }^{99}$ This new initiative was eventually approved by both houses (after the broader bill was first vetoed by the White House in October) in the National Defense Authorization Act in November 2015. The administration then directed the newly available funds to a broad range of support. ${ }^{70}$

The Obama administration appeared to respond to the assertive signaling and prodding of members of Congress from both houses and from both parties. Under pressure both from developing events and members of Congress, the administration expanded U.S. efforts across several dimensions. First, the administration engaged more broadly with allies and friends in the region. This engagement included maritime collaboration with Indonesia, Malaysia and Vietnam, and a growing list of joint training and exercises with members of ASEAN and others in the region, among other efforts. ${ }^{71}$ As Secretary of Defense Ashton Carter noted in a public speech on the matter, members of Congress were credited for their role: "DoD will be launching a new Southeast Asia Maritime Security Initiative. And thanks to the leadership of the Senators here today (emphasis added)... [ellipse as in original] and others, Congress has taken steps to authorize up to $\$ 425$ million dollars for these maritime capacity-building efforts." ${ }^{72}$ When established, the new initiative involved a range of efforts to increase

the maritime security capacity of our allies and partners, to respond to threats in waters off
their coasts and to provide maritime security more broadly across the region. We are not
only focused on boosting capabilities, but also helping our partners develop the necessary
infrastructure and logistical support, strengthen institutions, and enhance practical skills to
develop sustainable and capable maritime forces. ${ }^{73}$

Another highly salient element of this increased support occurred in late 2015 , when a $\$ 1.83$ billion arms sale was approved for Taiwan. ${ }^{74}$

Taking the cue from congressional prodding, the administration response also involved efforts to support ASEAN and encourage a united front in addressing China's actions. For example, in the fall of 2015, Secretary of State John Kerry and other administration officials worked with allies from Japan, Australia and New Zealand to convince ASEAN to include a joint statement on the South China Sea disputes at a conference of ASEAN's defense ministries, and supported and facilitated agreements among members such as Taiwan and the

${ }^{69}$ Ankit Panda, "US to Support Taiwan in South China Sea Per 2016 Defense Budget Bill," The Diplomat, October 4, 2015, http://thediplomat.com/2015/10/us-to-support-taiwan-in-south-china-sea-per-2016-defense-budget-bill/.

70 See "FACT SHEET: U.S. Building Maritime Capacity in Southeast Asia," The White House, November 17, 2015, https:// www.whitehouse.gov/the-press-office/2015/11/17/fact-sheet-us-building-maritime-capacity-southeast-asia.

71 Department of Defense, "Asia-Pacific Maritime Security Strategy," 24.

72 Quoted in O'Rourke, Maritime Territorial and Exclusive Economic Zone (EEZ) Disputes, 35.

73 "FACT SHEET: U.S. Building Maritime Capacity in Southeast Asia".

74 "China Slams US after B-52 Bomber Flies over Contested South China Sea Reef," Fox News, December 19, 2015, http:// www.foxnews.com/politics/2015/12/19/china-slams-us-after-b-52-bomber-flies-over-contested-south-china-sea-reef.print.html. 
Philippines to resolve their differences. ${ }^{75}$ Such efforts were resisted by China, which strongly preferred to address the competing claims on a bilateral basis.

The administration also increased its efforts to promote peaceful diplomatic solutions, including negotiations, arbitration, and other international legal mechanisms. In September 2015, for example, the Defense and State departments successfully completed an annex to the existing Memorandum of Understanding on commercial and military transit in the South China Sea to establish rules of behavior for safety of air-to-air encounters. ${ }^{76}$ Expanded efforts to collaborate with key allies on the issue also occurred as U.S. officials worked "closely with our friends in Australia, Japan, South Korea, and elsewhere to coordinate and amplify our efforts toward promoting peace, stability, and prosperity in Asia. In part, we are partnering trilaterally to achieve these goals." $" 77$

Another interesting element of the administration response was to increase the public visibility of U.S. efforts in a version of public diplomacy or signaling that was consistent with calls by Congress to increase U.S. involvement. In addition to speeches, attendance at meetings, and a variety of other efforts in the fall of 2015, one good example occurred in November when U.S. Secretary of Defense Ashton Carter took Malaysian Defense Minister Hishammuddin Hussein to visit the USS Theodore Roosevelt, an aircraft carrier conducting operations in the South China Sea. During the publicized visit, Carter told the press

\begin{abstract}
Being here on the Theodore Roosevelt in the South China Sea is a symbol and signifies the stabilizing presence that the United States has had in this part of the world for decades.... If it's being noted today in a special way, it's because of the tension in this part of the world, mostly arising from disputes over land features in the South China Sea, and most of the activity over the last year being perpetrated by China. ${ }^{78}$
\end{abstract}

The administration responded further by embracing congressional calls for increased activity "to reaffirm the principle of freedom of operations in international waters" (as stated in S.Res 412) and significantly expanded a program of "freedom of navigation operations" by the U.S. Navy in the region, designed to assert and demonstrate the U.S. commitment to maritime access to the disputed air and sea lanes claimed by China. Although such operations had been slowly increasing in general since 2013, ${ }^{79}$ Department of Defense testimony at a congressional hearing in September established that the United States had not conducted such operations in the South China Sea/Spratly Islands area after $2012 .{ }^{80}$ In response to congressional pressure, the administration decided in the early fall to initiate such operations as part of a more assertive and visible strategy. The first such operations occurred in October 2015, when the USS Lassen and P-8 patrol planes sailed in the disputed region. While China vigorously protested, the U.S. publicly confirmed the action as a measure to "rebuff of Beijing's territorial and maritime claims in the disputed waters." According to reporting, the White House decision to transit the disputed areas was intended to "assert the U.S. position that they lie in international waters where ships from all countries are free to travel," in the

75 See Yeganeh Torbati And Trinna Leong, "ASEAN Defense Chiefs Fail to Agree On South China Sea Statement," Reuters, November 4, 2015, http://www.reuters.com/article/us-asean-malaysia-statement-idUSKCN0ST07G20151104. Under lobbying pressure from China, ASEAN failed to reach agreement on the statement and did not include it.

76 O'Rourke, Maritime Territorial and Exclusive Economic Zone (EEZ) Disputes, 20.

77 Department of Defense, "Asia-Pacific Maritime Security Strategy," 28.

78 Yeganeh Torbati, "Pentagon Chief Visits U.S. Carrier in Disputed South China Sea, blames Beijing for tension," Reuters, November 5, 2015, http://www.reuters.com/article/us-southchinasea-usa-carter-idUSKCNOST35J20151105.

79 Department of Defense, "Asia-Pacific Maritime Security Strategy," 24.

${ }^{80}$ O'Rourke, Maritime Territorial and Exclusive Economic Zone (EEZ) Disputes, 40. 
word of an anonymous senior U.S. defense official. ${ }^{81}$ U.S. actions were quickly supported by officials from Australia and Japan, and U.S. defense officials confirmed that they expected to continue such operations at a rate of about twice per quarter going forward. ${ }^{82}$ In addition, this operation was followed by a number of overflights by U.S. B-52 bombers in November and December 2015 as well. ${ }^{83}$

Finally, in the first weeks of 2016, the Philippines cleared the way for a defense cooperation agreement with the U.S. to allow U.S. forces use of eight bases in that country, including two in the South China Sea - the first such arrangement since the end of U.S. basing rights twenty-five years earlier. According to one analyst, officials from both countries intended the agreement and deployment to deter China and "help convince the Chinese that pressuring its neighbors into giving up their territorial claims is actually not in China's interest." McCain (R-AZ), an advocate for more aggressive efforts in the region, noted "As Manila finds itself the target of Chinese coercion....and is looking to Washington for leadership, this agreement will give us new tools to deepen our alliance with the Philippines, expand engagement with the Philippine Armed Forces, and enhance our presence in Southeast Asia." $" 85$

\subsection{Phase 3: Into the future}

By the end of 2015, tension persisted and the U.S. response had generated mixed results. While more assertive actions and concerted efforts emerged in the wake of heightened concern, troubling developments, and congressional urging, the future of the dispute remained uncertain. For its part, China appeared ready to consolidate and extend its actions, moving forward in construction activities, initiating test flights and announcing plans for regular air traffic to newly established airfields. ${ }^{86}$ Tension between China, Vietnam, Taiwan, and the Philippines appeared greater in early 2016 because of these advancements.

For the U.S., the way forward remained unclear. Despite the more aggressive and concerted efforts, the territorial disputes in the area remained unresolved and fears of a Chinese fait accompli grew with each passing month as the reclamation and construction efforts continued. One Australian foreign policy specialist opined that "Ultimately...it may take a crisis for the U.S.-China relationship to reach a stable equilibrium." ${ }^{" 87}$ Other observers cautioned that the most visible efforts - the freedom of navigation operations - were likely a case of "too little, too late" unless accompanied by further and more assertive efforts, including not only more (and regular) such operations, but also joint flotillas involving the U.S., Japan, Australia, Vietnam and the Philippines, and perhaps even an international conference to demilitarize the entire region. ${ }^{88}$

For members of the U.S. Congress, 2015 ended with continued scrutiny and a readiness to press for further action. While the administration's responsiveness to congressional prodding

\footnotetext{
81 David Cloud and Julie Makinen, "China, Angered over Warship Patrol Near Artificial Islands, warns U.S. not to 'create trouble'," Los Angeles Times, October 26, 2015, http://www.latimes.com/world/asia/la-fg-navy-china-islands-20151026-story.html.

82 O'Rourke, Maritime Territorial and Exclusive Economic Zone (EEZ) Disputes, 42.

83 "China Slams US".

${ }^{84}$ Dan De Luce, "China Fears Bring the U.S. Military Back to the Philippines," Foreign Policy, January 12, 2016, http:// foreignpolicy.com/2016/01/12/china-fears-bring-the-u-s-military-back-to-the-philippines/.

85 Dan De Luce, "China Fears Bring".

86 David Brunnstrom, "China Seeks Investment for Disputed Islands, to Launch Flights," Reuters, January 15, 2016, http:// www.reuters.com/article/us-southchinasea-china-idUSKCNOUT0QR.

${ }_{87}$ Cloud and Makinen, "China, Angered over Warship".

88 Arthur Herman, "The Showdown in the South China Sea," The National Review, January 6, 2016, http://www.nationalreview. com/node/429281/print.
} 
in 2015 assuaged members to some degree, the uncertainty led many to remain concerned. For example, in December 2015, a bipartisan group of House members publicly offered support for Taiwan and its efforts to counter Chinese actions and resolve disputes with the other claimants in the region. ${ }^{89}$ Similarly, Rep. Randy Forbes (R-VA) continued to circulate information about events in the region and to urge attention and action in response. ${ }^{90}$ As 2016 began, members appeared to be in a "strategic pause," wary and monitoring the situation to gauge the significant of China's actions, the results and progress of administration responses, and the need for further pressure and action.

As time passed, congressional frustration grew, however, and congressional signaling and pressure increased. Many members of Congress preferred a more confrontational approach to China's continued expansion of activities in the South China Seas, while the Obama administration took a more restrained approach that reflected concerns over cooperation with China on climate change and other issues. ${ }^{91}$ As a consequence, citing the administration's "weak and lackluster" response, Sen. Corker joined with his colleagues Menendez, Cardin, and Cory Gardner (R-CO) to write President Obama urging action, and to introduce the "AsiaPacific Maritime Security Act” (S. 2865), legislation requiring expanded naval operations in the South China Seas and deeper military/security cooperation with other states of the region, including the Philippines. A similar bill (H.R. 5890) was introduced in the House in July, but both stalled in their respective committees. ${ }^{92}$

Congressional concerns persisted as 2016 passed, heightened by China's defiance of the July 2016 decision of the Permanent Court of Arbitration in the Hague (Netherlands) rejecting China's expansive claims in the region. ${ }^{93}$ The slow pace and eventual freezing of US Freedom of Navigation operations in the South China Seas in October 2016 raised further concerns. After the 2016 elections and the change in administration, members of Congress initially waited to see what the new administration's approach would be, encouraged by firm and assertive statements by Secretary of State nominee Rex Tillerson at his confirmation hearings calling for confrontation. ${ }^{94}$ However, assertiveness receded as the new administration sought cooperation with China to address North Korea's nuclear weapons program.

As a consequence, members of Congress took action to prod the reluctant administration forward, combining signals, hearings, and the introduction of legislation to press their preferences for a different, more assertive approach. For example, seven senators wrote to the White House urging more aggressive actions, including the resumption of naval patrols in the South China Seas. According to one congressional aide, "We thought it was important to weigh in and also to try to help shake things loose in the administration on this." ${ }^{95}$ Corker, still chairman of the Foreign Relations Committee, joined with Sens. Marco Rubio (R-Fla.), Cory Gardner (R-Colo.), Benjamin Cardin (D-Md.), Jack Reed (D-R.I.), Edward Markey

\footnotetext{
${ }^{89}$ Rita Cheng and Elaine Hou, "U.S. Congress Members Support Taiwan's Initiatives in South China Sea," Focus Taiwan, December 19, 2015, http://focustaiwan.tw/news/aipl/201512190005.aspx.

90 See, for example, his China Caucus Blog, https://forbes.house.gov/chinacaucus/blog/.

91 Dan DeLuce, "Lawmakers to White House: Get Tough with Beijing over South China Sea," Foreign Policy, April 27, 2016, http://foreignpolicy.com/2016/04/27/lawmakers-to-white-house-get-tough-with-beijing-over-south-china-sea/.

92 See DeLuce, "Lawmakers to White House," and S.2865, 114th Cong., 2nd sess (2016), https://www.congress.gov/bill/114th-congress/senate-bill/2865/text.

93 Jane Perlez, "Tribunal Rejects Beijing's Claims in South China Sea,” New York Times, July 12, 2016, https://www.nytimes. com/2016/07/13/world/asia/south-china-sea-hague-ruling-philippines.html.

94 Michael Forsythe, "Rex Tillerson's South China Sea Remarks Foreshadow Possible Foreign Policy Crisis," New York Times, January 12, 2017, https://www.nytimes.com/2017/01/12/world/asia/rex-tillerson-south-china-sea-us.html.

${ }_{95}$ Dan DeLuce, "Senators to Trump: Show Resolve with Beijing in South China Sea," Foreign Policy, May 10, 2017, http:// foreignpolicy.com/2017/05/10/senators-to-trump-show-resolve-with-beijing-in-south-china-sea/.
} 
(D-Mass.), and Brian Schatz (D-Hawaii) on the letter. In addition, Rubio introduced the "South China Sea and East China Sea Sanctions Act of 2017" (S.659) in March, legislation that would escalate U.S. responses to include entry and property sanctions (currently pending in committee at this writing). ${ }^{96}$ In response, the administration ended its freeze of naval operations in the region (it had denied several requests from the Department of Defense for such operations) and, in May, authorized the first such action of its tenure in office. ${ }^{97}$ Administration officials including Secretary of State Tillerson and Secretary of Defense James Mattis also delivered more assertive warnings to China public statements during travel in the region in June, and the administration increasingly embraced an approach similar to its predecessor, with somewhat more emphasis on shows of force. ${ }^{98}$

\section{Conclusion: Congress, the South China Sea, and Congressional Engagement in Foreign Policy}

Examining U.S. policymaking on the South China Sea dispute through the analytical framework employed in this chapter sheds light on how and why the U.S. response to the challenge unfolded as it did. As the preceding discussion indicates, members of Congress were significant players in the 2014-2015 period, and beyond, and their role and influence is better understood when seen through the analytical lens employed here.

First, congressional engagement generally took shape according to the sequence and dynamics of the analytical framework. On this strategic policy issue, members first deferred to and monitored administration responses. The complex array of interests in the U.S.-China relationships and the significant stakes involved in both the South China Sea dispute and the broader relationship contributed to broader, more bipartisan concerns. As the problem developed and concerns over the nature of the administration response grew, members engaged in indirect and non-legislative efforts to signal their concerns and push the administration toward further action and policy development. Framing, oversight, and reliance on the annual budgetary cycle were central to these efforts. While the executive-dominated instruments involved in the matter (military force, diplomacy) constrained congressional opportunities to some degree, the legislative-dominated instruments of the power of the purse offered opportunities to shape policy. Members moved to more assertive efforts after the first phase of policymaking in 2014, and exerted significance influence - through both anticipated reactions and through direct-legislative measures - in 2015, after "surveilling" the administration response and finding it lacking. As concerns with administration responses to their prodding ensued, such actions became increasingly direct, with clearer and more binding actions specified in proposed legislation in 2015-2017.

Second, the preceding analysis shows the significance of key individual members in driving congressional engagement and influence. Attentive members in key committees were central to the use of indirect and non-legislative activities that prodded the administration. These members led Congress with their activity and engagement, and their use of key access points in committee and subcommittees empowered them in efforts such as framing, signaling,

\footnotetext{
96 See South China Sea and East China Sea Sanctions Act of 2017, S.659, 115th Cong., (2017-2018),

https://www.congress.gov/bill/115th-congress/senate-bill/659.

${ }_{97}$ Ben Westcott and Barbara Starr, "South China Sea: US warship challenges China's claims with first operation under Trump," CNN, May 25, 2017, http://www.cnn.com/2017/05/24/politics/south-china-sea-us-mischief-reef/index.html.

98 Mark Valencia, "Trump's South China Sea policy taking shape," Japan Times, June 23, 2017, http://www.japantimes.co.jp/ opinion/2017/06/23/commentary/world-commentary/trumps-south-china-sea-policy-taking-shape/\#.WXIIQca-LGI.
} 
oversight, and the introduction of legislation. They acted as foreign policy entrepreneurs and were able to communicate preferences and signal the need for administration responses, and — as the Forbes example most clearly illustrates - they were able to inform, persuade and mobilize activity from other members of Congress, with the passage of legislation in 2015 as a key example. Thus, the multiple avenues cued by the analytical framework revealed a broader range of activity and influence by Congress, and a more important role for the institution in shaping the U.S. response.

In this context, this analysis sheds some light on the role and influence of the more indirect and non-legislative efforts, especially regarding signaling and anticipated reactions. As members signaled their concerns, administration reception and responsiveness was heightened by their nature. Signals by a president's own party members are generally more powerful, ${ }^{99}$ while signals from members of Congress from the opposite party are less so. In this case, the bipartisan signals were particularly important and consequential. Moreover, the administration reaction - responsiveness to members of Congress and their preferences and signals - shaped the nature of the ensuing legislative-executive interactions as well. To be sure, U.S. policy responses were not solely attributable to congressional action, but the sequences and action-reaction processes strongly suggest anticipated reactions and additional, more direct effects (e.g., 2015 legislation).

Third, partisanship played a significant, but limited role in this issue. The nature of the challenge and its broader stakes, along with the array of economic interests and global concerns that connect the U.S. and China, as well as the interests of various factions of the U.S. political system, worked to establish competing interests and priorities that muted partisanship and generated more cooperative efforts. Such conditions frequently reduce the impact of partisan foreign policy behavior, as many studies of post-World War II conclude. ${ }^{100}$ However, at least two indications of the partisan aspect emerged. First, the more partisan House of Representatives, with its Republican majority, took a more critical approach. It is noteworthy that, while the Senate regularly invited administration witnesses to its hearings, the House regularly did not, relying on critical policy analysts from foreign policy institutes and the like. Second, when Republicans gained control of the Senate in 2015, more critical and assertive efforts ensued. To be sure, the arc of the challenge accounts for some of this, but it is also apparent from hearings transcripts that Republican members were consistently more critical and more demanding of forceful responses than their Democratic colleagues. Moreover, as noted, hearings in the Senate Foreign Relations and Senate Armed Services committees increased substantially in 2015 , driven in part by developments in the regions, but also by the changed partisan control of the chamber.

\footnotetext{
99 See Carter and Scott, Choosing to Lead; Ralph G. Carter and James M. Scott, "Understanding Congressional Foreign Policy Innovators: Mapping Entrepreneurs and their Strategies," Social Science Journal 47, no. 2 (2010): 418-38; J. William Fulbright, The Arrogance of Power (New York: Vintage Books, 1966), 105.

${ }^{100}$ See, for example, McCormick and Wittkopf, "Bipartisanship, Partisanship, and Ideology," 1077-100; McCormick, Wittkopf, and Danna, "Politics and Bipartisanship at the Water's Edge"; Richard Melanson, American Foreign Policy since the Vietnam War: The Search for Consensus from Nixon to Clinton (Armonk, NY: M.E. Sharpe, 1996); Lindsay, Congress and the Politics of U.S. Foreign Policy; Carter and Scott, Choosing to Lead; Joseph Cooper and Garry Young, "Partisanship, Bipartisanship, and Crosspartisanship in Congress since the New Deal," in Congress Reconsidered, $6^{\text {th }}$ ed., ed. Lawrence. C. Dodd and Bruce I. Oppenheimer (Washington, DC: CQ Press, 1997), 246-73; Peter Trubowitz, Politics and Strategy: Partisan Ambition and American Statecraft (Princeton: Princeton University Press, 2011); Dina Smeltz, Ivo Daalder, Karl Friedho, and Craig Kafura, America Divided: Political Partisanship and US Foreign Policy (Chicago: Chicago Council on Global Affairs, 2015).
} 
Overall, the nature and patterns of the U.S. foreign policymaking and the response to the South China Sea challenge are better understood and explained when inspected through the lens of this analytical framework. Looking forward, as the challenge continues, members of Congress are likely to continue their strategic approach, monitoring both the problem and the administration's response to it, gauging progress and the need for policy correction, and relying on key individuals to take the lead in congressional engagement and activity. With progress, members are likely to defer; without it, they are likely to engage more aggressively, prodding the administration to take further action, or charting new courses should the administration prove unwilling to do so. In any event, members of Congress will be meaningful players in shaping the nature of the U.S. response to the South China Sea challenge in the future.

\section{Bibliography}

Arnold, Douglas. The Logic of Congressional Action. New Haven: Yale University Press, 1990.

Brunnstrom, David. "China Seeks Investment For Disputed Islands, to Launch Flights.” Reuters, January 15, 2016. http://www.reuters.com/article/us-southchinasea-china-idUSKCNOUT0QR.

Burden, Barry. Personal Roots of Representation. Princeton, NJ: Princeton University Press, 2007.

Carter, Ralph, and James M. Scott. Choosing to Lead: Understanding Congressional Foreign Policy Entrepreneurs. Durham, NC: Duke University Press, 2009.

— . "Understanding Congressional Foreign Policy Innovators: Mapping Entrepreneurs and their Strategies." Social Science Journal 47, no. 2 (2010): 418-38.

Cheng, Rita, and Elaine Hou. "U.S. Congress Members Support Taiwan's Initiatives in South China Sea." Focus Taiwan, December 19, 2015. http://focustaiwan.tw/news/aip1/201512190005.aspx.

Cloud, David, and Julie Makinen. "China, Angered over Warship Patrol Near Artificial Islands, warns U.S. not to 'create trouble'." Los Angeles Times, October 26, 2015. http://www.latimes.com/world/asia/la-fg-navy-chinaislands-20151026-story.html.

Conley, Richard. "Congress, the Presidency, Information Technology, and the Internet: Policy Entrepreneurship at Both Ends of Pennsylvania Avenue." In Congress and the Internet, edited by James A. Thurber and Colton C. Campbell, 135-60. Upper Saddle River, NJ: Prentice-Hall, 2003.

Cooper, Joseph, and Garry Young. "Partisanship, Bipartisanship, and Crosspartisanship in Congress since the New Deal.” In Congress Reconsidered, $6^{\text {th }}$ ed., edited by Lawrence. C. Dodd and Bruce I. Oppenheimer, 246-73. Washington, DC: CQ Press, 1997.

DeLaet, C. James, and James M. Scott. "Treaty Making and Partisan Politics: Arms Control and the U.S. Senate, 1960-2001.” Foreign Policy Analysis 2 (2006): 177-200.

DeLuce, Dan. "China Fears Bring the U.S. Military Back to the Philippines.” Foreign Policy, January 12, 2016. http://foreignpolicy.com/2016/01/12/china-fears-bring-the-u-s-military-back-to-the-philippines/.

— .Lawmakers to White House: Get Tough with Beijing over South China Sea." Foreign Policy, April 27, 2016. http://foreignpolicy.com/2016/04/27/lawmakers-to-white-house-get-tough-with-beijing-over-southchina-sea/.

. "Senators to Trump: Show Resolve with Beijing in South China Sea." Foreign Policy, May 10, 2017. http:// foreignpolicy.com/2017/05/10/senators-to-trump-show-resolve-with-beijing-in-south-china-sea/.

Forsythe, Michael. "Rex Tillerson's South China Sea Remarks Foreshadow Possible Foreign Policy Crisis." New York Times, January 12, 2017. https://www.nytimes.com/2017/01/12/world/asia/rex-tillerson-south-china-seaus.html.

Friedrich, Carl J. Constitutional Government and Democracy: Theory and Practice in Europe and America, rev.ed. Boston: Little, Brown, 1941. 
Fulbright, J. William. The Arrogance of Power. New York: Vintage Books, 1966.

. The Crippled Giant: American Foreign Policy and Its Domestic Consequences. New York: Random House, 1972.

Garrison, Jean. Making China Policy: From Nixon to G.W. Bush. Boulder, CO: Lynne Rienner, 2005.

George, A., and A. Bennett. Case Studies and Theory Development in the Social Sciences. Cambridge, MA: MIT

Press, 2005.

Goldsmith, Jack. "Letter from Heads of SFRC and SASC to Kerry and Carter on South China Sea." Lawfare, March 20, 2015. https://www.lawfareblog.com/letter-heads-sfrc-and-sasc-kerry-and-carter-south-china-sea.

Herman, Arthur. "The Showdown in the South China Sea." The National Review, January 6, 2016. http://www. nationalreview.com/node/429281/print.

Hermann, Charles. International Crises: Insights from Behavioral Research. New York: Free Press, 1972.

Routledge, 2011.

Hersman, Rebecca. Friends and Foes: How Congress and the President Really Make Foreign Policy. Washington, DC: Brookings, 2000.

Howell, William, and Jon Pevehouse. While Dangers Gather: Congressional Checks on Presidential War Powers. Princeton, NJ: Princeton University Press, 2007.

Hurst, Steven. "Parties, Polarization, and US Foreign Policy." In Obama and the World: New Directions in US Foreign Policy, $2^{\text {nd }}$ edition, edited by Inderjeet Parmar, Linda B. Miller, and Mark Ledwidge. New York, NY: Routledge, 2014.

Jeon, Yongjoo, and Donald Haider-Markel. "Tracing Issue Definition and Policy Change: An Analysis of Disability Issue Images and Policy Response.” Policy Studies Journal 29 (2001): 215-31.

Jochim, Ashley, and Bryan D. Jones. "Issue Politics in A Polarized Congress." Political Research Quarterly 66, no. 2 (2013): 352-69.

Kazianis, Harry. "Can Congress Stop China in the South China Sea." The National Interest, March 22, 2015. http:// nationalinterest.org/print/feature/can-congress-stop-china-the-south-china-sea-12459.

Kerry, John. "Remarks on U.S.-China Relations." Remarks at the Johns Hopkins School of Advanced International Studies Washington, DC, November 4, 2014. http://www.state.gov/secretary/remarks/2014/11/233705.htm.

Kingdon, John. "Models of Legislative Voting." Journal of Politics 39 (1977): 563-95.

Kriner, Douglas. After the Rubicon: Congress, Presidents, and the Politics of Waging War. Chicago, IL: The University of Chicago Press, 2010.

Levy, J. "Case Studies: Types, Designs, and Logics of Inference." Conflict Management and Peace Science 25 (2008): 1-18.

Lijphart, A. "Comparative Politics and the Comparative Method." American Political Science Review 65, no. 3 (1971): 682-93.

Lindsay, James. “Congress and Foreign Policy: Why the Hill Matters.” Political Science Quarterly 107 (1993): 613. - Congress and the Politics of US Foreign Policy. Baltimore, MD: Johns Hopkins University Press, 1994.

Loomis, Burdett, and Wendy Schiller. The Contemporary Congress, 5th ed. Belmont, CA: Wadsworth Publishing, 2005.

Mayhew, David. America's Congress: Actions in the Public Sphere, James Madison through Newt Gingrich. New Haven, CT: Yale University Press, 2000.

McCormick, James, and Eugene Wittkopf. "Bipartisanship, Partisanship, and Ideology in Congressional-Executive Foreign Policy Relations, 1947-1988.” Journal of Politics 52 (1990): 1077-100.

McCormick, James, Eugene Wittkopf, and David Danna. "Politics and Bipartisanship at the Water's Edge: A Note on Bush and Clinton.” Polity 30, no. 1 (1997):133-50.

McCormick, James, and Neil J. Mitchell. "Commitments, Transnational Interests, and Congress: Who Joins the 
Melanson, Richard. American Foreign Policy since the Vietnam War: The Search for Consensus from Nixon to Clinton. Armonk, NY: M.E. Sharpe, 1996.

O'Rourke, Ronald. Maritime Territorial and Exclusive Economic Zone (EEZ) Disputes Involving China: Issues for Congress (CRS Report No. R42784). Washington, DC: Congressional Research Service, December 22, 2015.

Oneal, John, and Anna Lillian Bryan. "The Rally 'Round the Flag Effect in U.S. Foreign Policy Crises: 1950-1985." Political Behavior 17 (1995): 379-401.

Panda, Ankit. "US to Support Taiwan in South China Sea Per 2016 Defense Budget Bill.” The Diplomat, October 4, 2015. http://thediplomat.com/2015/10/us-to-support-taiwan-in-south-china-sea-per-2016-defense-budget-bill/.

Pastor, Robert. Whirlpool: US Foreign Policy toward Latin America and the Caribbean. Princeton, NJ: Princeton University Press, 1992.

Perlez, Jane. "Tribunal Rejects Beijing's Claims in South China Sea.” New York Times, July 12, 2016. https://www. nytimes.com/2016/07/13/world/asia/south-china-sea-hague-ruling-philippines.html.

Rapp-Hooper, Mira. "Before and After: The South China Sea Transformed." Asia Maritime Transparency Initiative. Center for Strategic and International Studies, February 18, 2015.

Ripley, Randall, and Grace Franklin. Congress, the Bureaucracy, and Public Policy. Pacific Grove, CA: Brooks/ Cole, 1990.

Ripley, Randall, and James Lindsay. "Foreign and Defense Policy in Congress: An Overview and Preview." In Congress Resurgent: Foreign and Defense Policy on Capitol Hill, edited by Randall Ripley and James Lindsay, 3-16. Ann Arbor, MI: University of Michigan Press, 1993.

Rudalevige, Andrew. "The Executive Branch and the Legislative Process." In The Executive Branch, edited by Joel D. Aberbach and Mark A. Peterson, 419-51. New York: Oxford University Press, 2005.

Schraeder, Peter. United States Foreign Policy toward Africa: Incrementalism, Crisis and Change. Cambridge: Cambridge University Press, 1994.

Scott, James M. Deciding to Intervene: The Reagan Doctrine and American Foreign Policy. Durham, NC: Duke University Press, 1996.

— . "In the Loop: Congressional Influence in American Foreign Policy." Journal of Political and Military Sociology 25 (1997):47-76.

Scott, James M., and Ralph Carter. "Acting on the Hill: Congressional Assertiveness in U.S. Foreign Policy." Congress \& the Presidency 29 (2002):151-69.

- "The Not-So-Silent Partner: Patterns of Legislative-Executive Interaction on the War on Terror." International Studies Perspectives 15, no. 2 (2014): 186-208.

Smeltz, Dina, Ivo Daalder, Karl Friedho, and Craig Kafura. America Divided: Political Partisanship and US Foreign Policy. Chicago: Chicago Council on Global Affairs, 2015.

Smith, Steven. "Congressional Party Leaders." In The President, The Congress, and the Making of Foreign Policy, edited by Paul E. Peterson, 129-60. Norman, OK: University of Oklahoma Press, 1994.

Torbati, Yeganeh. "Pentagon Chief Visits U.S. Carrier in Disputed South China Sea, blames Beijing for tension.” Reuters, November 5, 2015. http://www.reuters.com/article/us-southchinasea-usa-carteridUSKCNOST35J20151105.

Torbati, Yeganeh, and Trinna Leong. "ASEAN Defense Chiefs Fail to Agree on South China Sea Statement.” Reuters, November 4, 2015. http://www.reuters.com/article/us-asean-malaysia-statement-idUSKCN0ST07G20151104.

Trubowitz, Peter. Politics and Strategy: Partisan Ambition and American Statecraft. Princeton: Princeton University Press, 2011.

Trubowitz, Peter, and Nicole Mellow. "Foreign Policy, Bipartisanship and the Paradox of Post-September 11 America." International Politics 48 (2011):164-87.

Valencia, Mark. “Trump's South China Sea policy taking shape.” Japan Times, June 23, 2017. http://www. japantimes.co.jp/opinion/2017/06/23/commentary/world-commentary/trumps-south-china-sea-policy-takingshape/\#.WXIlQca-LGI. 
Van Evera, S. Guide to Methods for Students of Political Science. Ithaca, New York: Cornell University Press, 1997. Wawro, Gregory. Legislative Entrepreneurship in the U.S. House of Representatives. Ann Arbor: University of Michigan Press, 2001.

Webb Hammond, Susan. "Congressional Caucuses in the Policy Process." In Congress Reconsidered, 4th ed., edited by Lawrence Dodd and Bruce Oppenheimer., 351-71. Washington: CQ Press, 1989.

Westcott, Ben, and Barbara Starr. "South China Sea: US warship challenges China's claims with first operation under Trump." CNN, May 25, 2017. http://www.cnn.com/2017/05/24/politics/south-china-sea-us-mischiefreef/index.html. 